\title{
The Effect of European Union Membership on Welfare
}

\author{
Ender Sevinç $^{1} \&$ Abdülkadir Civan ${ }^{2}$ \\ ${ }^{1}$ Department of Economics, Marmara University, İstanbul, Turkey \\ ${ }^{2}$ Department of Economics, Gediz University, İzmir, Turkey \\ Correspondence: Ender Sevinç, Department of Economics, Marmara University, Göztepe, Kadıköy, İstanbul \\ 34722, Turkey. Tel: 90-535-609-4505. E-mail: ender.sevinc@marmara.edu.tr
}

Received: December 5, 2012 Accepted: January 8, 2013 Online Published: February 18, 2013

doi:10.5539/res.v5n1p65 URL: http://dx.doi.org/10.5539/res.v5n1p65

A previous version of that paper was part of Ender Sevinc's master thesis.

\begin{abstract}
We study the impact of EU membership on the per capita income, longevity and welfare of the member states. We utilize the concept of full income developed by Becker, Philipson and Soares (2005) which takes into consideration not only in the income level but also increase in the expected lifetime. Our results indicate that there is convergence among EU countries in per capita income, expected lifetime and welfare. Convergence speed is the highest in the per capita income whereas the slowest in the welfare. Moreover our estimations indicate that EU membership positively affects income, longevity, and welfare growth rates.
\end{abstract}

Keywords: European Union, convergence, full income, welfare

\section{Introduction}

Main goal of European Union is the coordination and coherence in the economic, social, and political policies of its member states. Thus it forces certain policies on member states through variety of mechanisms. Assuming those enforced policies are "right policies" than we would expect that welfare of the countries improve after accession to the Union. Indeed even superficial observations suggest that membership speeds up the development pace of the countries. More methodological academic studies confirm those observations as well. Most of these studies conclude that latter members to the Union which are generally less developed ones catch up the former ones which are more developed on many economic indicators such as per capita income and inflation rate (Crespo-Cuaresma, Dimitz \& Ritzberger-Grünwald, 2002).

EU can help member countries' development paces through variety of mechanisms. EU aims to establish a supranational union where member countries follow identical or very similar economic, social, and political policies. In this organization not only final goods would be traded between countries but also inputs of production and technology would be free to move (Macdonald, 1994; Caves \& Barton, 1990; Lee, 1992). Those factors tend to improve the technology and efficiency (Kar \& Arrkan, 2003). Since all regulations are very similar, individuals and organizations are be able to enjoy benefits stemming from being in a large market including economies of scale and specialization.

Growth and development studies proved that good or bad institutions can have tremendous influence over the societies' development paces. Sometimes economic, social and cultural reasons prevent the establishment of good institutions locally. (Note 1) It has been argued that EU can help member or candidate countries to set up good institutions. Then good institutions speed up economic and social progress. Moreover EU's regulatory power provides an opportunity to internalize inter-country externalities, and help to achieve a sustainable development. Besides, EU subsidies on many sectors directly benefit member countries.

EU is not only an economic organization but also a social and political one. In fact Acquis regulates every aspect of the life in the member states. Thus we expect a significant influence of accession to the Union on many aspects of the life on the member states. Although economists have started to concentrate on the other aspects of welfare such as health, education, and freedom etc...most studies on EU focused on the economic effects. As it is known that there are many factors which affect the welfare, so the identification of welfare function is a very complex task. The Human Development Index (HDI) is one of the leading measurements of welfare, which is a 
weighted average of the life expectancy, years of schooling and per capita income. The data of the life expectancy index and education index are in terms of years, whereas income index is in terms of GNI per capita (PPP US\$). Although HDI is an improvement over simple per capita numbers, the relative crudeness and ad hoc nature of it reduce its usefulness (Philipson \& Soares 2001). In order to study the effect of membership of $\mathrm{EU}$ on the welfares of individuals we used the concept of full income which was developed by Rosen (1988) and simplified by Becker, Philipson and Soares (2005) and Soares (2007). The full income is a combination of income and life expectancy and gives a monetary value to the increase in life expectancy. In technical terms it is equivalent variation of increases in longevity. In other words it attempts to estimate individuals' own willingness to pay for the increases in expected lifetime. In this line, we define the welfare in terms of yearly income as the sum of personal income and monetary value of longevity. We studied the impact of accession to the Union on the welfare of the citizens of countries. Moreover since member countries follow very similar economic, politic and social policies; by the time, convergence of many economic and social indicators is expected. We also investigated the existence of convergence on per capita income, longevity and welfare (full income) among member countries.

The rest of the paper is organized as follows: First we provide the background information about the convergence method and its application in EU context. Later we study the influence of EU membership on the countries per capita income and expected lifetime and the existence and speed of convergence on EU using the similar data and methodology to the ones used in the literature. In part 3 we provide the methodology of full income calculation, the results and discussion. Part 4 concludes.

\section{Convergence in $\mathbf{E U}$}

The principal definition of convergence is given by Barro and Sala-i Martin (1992) where they studied the level and growth rate of per capita incomes of US states between 1880 and 1988. There are several types of convergence. $\beta$ convergence is defined by Barro and Sala-i Martin (2004) as the negative correlation between initial level of per capita income and its growth rate. According to that definition if high income economies grow slower than low income economies, the existence of $\beta$ convergence is claimed.

Barro and Sala-i Martin (2004) defined the $\sigma$ convergence as decreasing dispersion of per capita GDP within a set of countries and groups. The dispersion can be tested with cross-sectional standard deviation of the logarithm of real GDP per capita or coefficient of variation which is the standard deviation over the mean of the sample.

Barro and Sala-i Martin (2004) defined the unconditional (absolute) $\beta$ convergence that the high income economies grow slower than the low income economies without controlling for anything which might affect the growth rate. In unconditional convergence theory, it is assumed that the samples converge to a unique steady state level and all variables affect the steady state positions of economies evenly. In conditional convergence theory, each economy converges to its own steady state level, so different steady state levels for different economies are presumed.

\subsection{Economic Convergence in EU}

Crespo-Cuaresma et al. (2002) studied 15 EU member countries and showed the convergence of per capita incomes in EU. They investigated the EU countries between 1960 and 1998, and used investment rate, the years of education, average inflation rate, government consumption share, openness and length of EU membership as control variables. They showed the existence of conditional and unconditional $\beta$ convergence among EU countries. According to their results, the real GDP per capita dispersion was decreasing between 1960 and 1998 . This means there was $\sigma$ convergence between 15 EU countries. They also showed that EU membership benefits poor countries more than the rich countries.

Barro and Sala-i Martin (2004) showed the existence of $\sigma$ convergence across European regions from 1950 to 1990. Also, they found some evidence of the existence of convergence across countries. Falk and Sinabell (2008) supported the Barro and Sala-i Martin (2004)'s results but with a slower rate which was $0.5 \%$ per year. Also, Reza and Zahra (2008) proved that there was unconditional convergence among 10 new EU members between 1995 and 2005. Beugelsdijk and Sylvester (2005) showed the positive impact of the Structural Funds in the new members' economies and proved that the developing members tended to catch up to the developed members. Kutan and Yigit (2007) showed that EU membership was enhancing the productivity and productivity growth, also Structural Funds and Cohesion Funds had extremely important role in this growth.

In contrary to others, Vanhoudt (1999) investigated the effect of EU membership and he did not find any relationship between growth and EU membership in the long run. 
Table 1. Statistics of the logarithm of real GDP per capita (1980-2009)

\begin{tabular}{lllll}
\hline & 1980 & 1990 & 2000 & 2009 \\
\hline Minimum & 7.194 & 7.450 & 7.354 & 7.851 \\
Maximum & 9.950 & 10.388 & 10.746 & 10.912 \\
Mean & 9.062 & 9.147 & 9.304 & 9.552 \\
Standard Deviation & 0.813 & 0.826 & 0.939 & 0.791 \\
Coefficient of Variation & 0.089 & 0.090 & 0.100 & 0.082 \\
\hline
\end{tabular}

Table 1 represents the some statistics of the logarithm of real GDP per capita. The standard deviation of 27 EU members' per capita income is progressing slowly in 1980s. There is a little change in the dispersion of the personal income. However, the dispersion starts to rise up in the beginning of 1990s and reaches to 0.94 in 2000. In 2000 s, the $\sigma$ convergence could be seen easily, because the per capita income inequality between poor member countries and rich ones decreases from 0.94 to 0.79 . Similarly, the coefficient of variation, which is about 0.1 in 1990 s, decreases to 0.08 in 2009 .

Table 2. The growth rate of economies in EU (1980-2009)

\begin{tabular}{lccccc}
\hline & Accession & $1980-1989$ & $1990-1999$ & $2000-2009$ & $1980-2009$ \\
\hline European Union & & 0.236 & 0.199 & 0.119 & 0.772 \\
Austria & 1995 & 0.189 & 0.238 & 0.142 & 0.815 \\
Belgium & 1957 & 0.183 & 0.201 & 0.122 & 0.706 \\
Bulgaria & 2007 & 0.397 & -0.162 & 0.494 & 0.682 \\
Cyprus & 2004 & 0.704 & 0.431 & 0.320 & 2.634 \\
Czech R. & 2004 & & -0.010 & 0.336 & 0.370 \\
Denmark & 1973 & 0.208 & 0.248 & 0.055 & 0.674 \\
Estonia & 2004 & 0.274 & -0.136 & 0.443 & 0.618 \\
Finland & 1995 & 0.344 & 0.163 & 0.162 & 0.925 \\
France & 1957 & 0.235 & 0.170 & 0.109 & 0.710 \\
Germany & 1957 & 0.196 & 0.193 & 0.051 & 0.630 \\
Greece & 1981 & 0.070 & 0.206 & 0.333 & 0.800 \\
Hungary & 2004 & 0.160 & 0.024 & 0.220 & 0.488 \\
Ireland & 1973 & 0.315 & 0.813 & 0.313 & 2.720 \\
Italy & 1957 & 0.243 & 0.128 & 0.014 & 0.505 \\
Latvia & 2004 & 0.407 & -0.296 & 0.431 & 0.394 \\
Lithuania & 2004 & & -0.302 & 0.505 & 0.084 \\
Luxembourg & 1957 & 0.539 & 0.507 & 0.286 & 2.409 \\
Malta & 2004 & 0.379 & 0.531 & 0.117 & 1.665 \\
Netherlands & 1957 & 0.196 & 0.313 & 0.120 & 0.907 \\
Poland & 2004 & & 0.391 & 0.410 & 1.046 \\
Portugal & 1986 & 0.324 & 0.287 & 0.052 & 0.939 \\
Romania & 2007 & 0.138 & -0.175 & 0.511 & 0.367 \\
Slovak R. & 2004 & 0.109 & 0.028 & 0.518 & 0.755 \\
Slovenia & 2004 & & 0.146 & 0.292 & 0.546 \\
Spain & 1986 & 0.286 & 0.254 & 0.229 & 1.163 \\
Sweden & 1995 & 0.232 & 0.177 & 0.162 & 0.779 \\
UK & 1973 & 0.297 & 0.236 & 0.140 & 0.915 \\
\hline & & & & &
\end{tabular}


Table 2 shows the economic growth rate of EU and member countries. Some members do not have data for 1980-1989 period, so the growth rate in the period of 1980-2009 implies the growth rate in the period of 1990-2009 for these countries. According to the table, former and developed members' economic growth rates are decreasing while newly and developing members' economic growth rates are enhancing. Especially, the latest members are affected positively in the beginning of $21^{\text {th }}$ century and their economies start to recover after demolition of the eastern bloc. Casual observation suggests that there is convergence in EU and accession to the Union speeds up the growth rate. However we will also formally test the convergence of income per capita by the commonly used method in the literature.

In order to show the existence of the convergence we have to divide the data into subgroups. Barro and Sala-i Martin (2004) suggested that ten year periods are appropriate for studying convergence among economies. Following their suggestion we divide our data into ten year periods. So we have three ten year periods which are (1980-1989), (1990-1999) and (2000-2009). Our data include 27 EU member countries.

The growth rate of real GDP per capita is the dependent variable of our model, whereas initial level of per capita income and control variables are identified as independent variables. We added EU membership dummy to the base model used by Crespo-Cuaresma et al. (2002). (Note 2) The estimated following model:

$$
\left[\ln \left(y_{\mathrm{t}, \mathrm{i}}\right)-\ln \left(y_{t, i}\right)\right] / n_{t}=\alpha+\beta \cdot \ln \left(y_{t, i}\right)+\beta_{2} \cdot O P E N_{t, i}+\beta_{3} \cdot I N F_{t, i}+\beta_{4} . I N_{t, i}+\beta_{5} \cdot G O V E X P_{t, i}+\beta_{6} \cdot S C H_{t, i}+\beta_{7} \cdot N O Y_{t, i}+\beta_{8} \cdot D U M M Y_{t, i}+u_{t, i}
$$

The information about the variables is represented in Table 3 .

Table 3. The variables and definitions

\begin{tabular}{|c|c|c|c|}
\hline & Variable & Definition & Source \\
\hline $\mathrm{y}$ & $\begin{array}{l}\text { Initial income per } \\
\text { capita }\end{array}$ & $\begin{array}{l}\text { The initial level of real GDP per capita at } \mathrm{t}^{\text {th }}(\mathrm{t} \text { is } \\
\text { 1980-1989, 1990-1999, 2000-2009) period for } \\
\text { countrv } i\end{array}$ & World Bank \\
\hline$y^{\prime}$ & Income per capita & The real GDP per capita in the last year of period & World Bank \\
\hline $\mathrm{L}$ & $\begin{array}{l}\text { Initial level of life } \\
\text { expectancy }\end{array}$ & $\begin{array}{l}\text { The initial level of life expectancy at period } t \text { for } \\
\text { country i. }\end{array}$ & World Bank \\
\hline $\mathrm{L}^{\prime}$ & $\begin{array}{l}\text { Life Expectancy in } \\
\text { the last year }\end{array}$ & $\begin{array}{l}\text { The life expectancy in the last year of period } t \text { for } \\
\text { country } i\end{array}$ & World Bank \\
\hline OPEN & Openness & $\begin{array}{l}\text { The average yearly openness rate in period } t \text { for } \\
\text { country } i\end{array}$ & $\begin{array}{l}\text { PENN World } \\
\text { Table } 6.3\end{array}$ \\
\hline INF & Inflation & $\begin{array}{l}\text { The average yearly inflation rate in period } t \text { for } \\
\text { country } i\end{array}$ & World Bank \\
\hline INV & Investment Rate & $\begin{array}{l}\text { The investment share in GDP in period } t \text { for } \\
\text { country } i\end{array}$ & $\begin{array}{l}\text { PENN World } \\
\text { Table } 6.3\end{array}$ \\
\hline GOVEXP & $\begin{array}{l}\text { Government } \\
\text { Expenditure Ratio }\end{array}$ & $\begin{array}{l}\text { The government expenditure share in GDP in } \\
\text { period } t \text { for country } \mathrm{i}\end{array}$ & $\begin{array}{l}\text { PENN World } \\
\text { Table } 6.3\end{array}$ \\
\hline $\mathrm{SCH}$ & School Attainment & $\begin{array}{l}\text { School attainment which is the average year of } \\
\text { total schooling in neriod } t \text { for countrv } i\end{array}$ & $\begin{array}{l}\text { Barro R. \& } \\
\text { I W I ee }(v\end{array}$ \\
\hline NOY & Number of Year & \multicolumn{2}{|c|}{ The years passed since the accession to EU of $\mathrm{i}^{\text {th }}$ country in period $\mathrm{t}$} \\
\hline DUMMY & Dummy & \multicolumn{2}{|c|}{$\begin{array}{l}\text { Takes the value of } 1 \text { when country } i \text { is a member of EU in period } t \\
\text { and takes the value of } 0 \text { when country } i \text { is not a member of EU in } \\
\text { period } t\end{array}$} \\
\hline $\mathrm{n}$ & The length & \multirow{3}{*}{\multicolumn{2}{|c|}{ The length of a period in terms of year }} \\
\hline$\alpha$ & Constant Term & & \\
\hline $\mathrm{u}$ & Error Term & & \\
\hline
\end{tabular}


In literature the speed of convergence is computed as;

$$
\lambda=-\frac{\ln \left(1+\beta \cdot n_{t}\right)}{n_{t}}
$$

where $\beta$ is the coefficient of initial level of real GDP per capita and $n_{t}$ is the number of year in a period (Lopez-Rodriguez, 2008).

The $\beta$ coefficient is estimated with panel data regression. $\beta$ coefficient gives information about the existence of convergence. If the sign of the coefficient is negative, this means that the developed countries grow slower than the poor ones. So, when the $\beta$ coefficient is negative, we can conclude the existence of the $\beta$ convergence.

\subsubsection{Results}

The results of model (1) are shown in Table 4. Fixed Effect panel data regression is used. $\ln \left(\mathrm{y}_{\mathrm{t}, \mathrm{i}}\right)$ is the logarithm of initial real GDP per capita in 1980 for the period 1980-1989, 1990 for 1990-1999 and 2000 for 2000-2009. The negative coefficient implies that there is conditional economic convergence among EU countries. Also, the convergence speed is almost $17 \%$. The coefficient is significant at $1 \%$ confidence intervals and $p$-val is equal to 0.000 . According to this coefficient, -0.0819 (0.0152), a one standard deviation decline in the logarithm of the initial per capita GDP (0.939 in 2000) would raise the growth rate of the logarithm of real personal income on impact by 0.076 . This means that poor EU countries grow faster than rich EU countries conditionally. Crespo-Cuaresma et al. (2002) also found the conditional convergence with the annual convergence speed between 3.5\% and 5.5\% where they used the data for $15 \mathrm{EU}$ countries between 1960 and 1998.

Table 4. Conditional $\beta$ economic convergence in EU (1980-2009)

\begin{tabular}{lll}
\hline Fixed Effect (within) regression & Coefficients & Standard Error \\
\hline Constant & $0.7202^{* * *}$ & $(0.1427)$ \\
Real GDP per Capita & $-0.0819^{* * *}$ & $(0.0152)$ \\
Openness & $0.0002^{* *}$ & $(0.0001)$ \\
Inflation & $-0.0002^{* * *}$ & $(0.00008)$ \\
Investment Rate & 0.0001 & $(0.0005)$ \\
Government Expenditure Rate & 0.0003 & $(0.0006)$ \\
School Attainment & -0.0002 & $(0.0031)$ \\
Number of Year & 0.0007 & $(0.0006)$ \\
Dummy & $0.0160^{* * *}$ & $(0.0049)$ \\
Observations & 72 & \\
\hline & within & 0.8300 \\
$\mathrm{R}^{2}$ & between & 0.1339 \\
& overall & 0.1255 \\
\hline
\end{tabular}

Note: All EU countries with data ranging from 1980 to 2009, divided into three periods: $1980-1989,1990-1999$ and 2000-2009. Robust standard errors in parenthesis. $* * *(* *)[*]$ means $1 \%(5 \%)[10 \%]$ significant. According to the Hausman Test, fixed effect panel data regression is more appropriate than random effect regression. The results are obtained with using STATA 11.

Openness is defined as the average ratio of international trade volume to the real GDP in ten year period. Regression results indicate that a positive relationship between openness and economic growth rate. The value of the coefficient is 0.0002 (0.0001), means that a one standard deviation increase in openness rate (48.011 in 2000) would rise the logarithm of per capita income growth rate by 0.009 . Previous studies also found the similar results (Crespo-Cuaresma et al., 2002; Harrison, 1996; Sachs \& Warner, 1995; Barro \& Sala-i Martin, 2004).

The coefficient of inflation (-0.0002), is significant at $1 \%$ and there is a negative correlation between growth rate of the per capita income and inflation, which means that a one standard deviation decrease in inflation rate (8.549 in 2000) would rise the logarithm of per capita income growth rate by 0.002 . Similar to our results, Crespo-Cuaresma et al. (2002) and Barro and Sala-i Martin (2004) found the negative and highly significant results. Coefficients for investment rate, government expenditures and school attainment are not significant. 
Since our main interest is not income convergence we have not further explored the reasons for these unexpected results.

The data of NOY are established with identifying the length of the EU membership in each period. The studies about the convergence showed that there is a positive relationship between length of the EU membership and growth rate of real GDP per capita (Crespo-Cuaresma et al., 2002). The estimated coefficient, 0.0007 (0.0006), is insignificant. The findings refer the positive and highly significant relationship between EU membership and the economic growth rate. The estimated coefficient, 0.016 (0.0049), implies that the EU membership influences the real GDP per capita growth rate positively and union membership contributes the economic growth by $1.6 \%$.

In short, the findings show that EU membership is effective in boosting economic growth. The new member countries tend to catch up with the developed countries thanks to economic effects of EU membership.

\subsection{Life Expectancy Convergence in EU}

Improving the health level and increasing the longevity play an indispensable role in people's well-being (Nordaus, 2002). Expected lifetime depends on social, environmental, cultural, genetic, economic and many other factors. Since EU has substantial influence over many of these, we test the existence of convergence of the expected lifetime in the EU countries. Although the relationship between economic factors and health is very complex and very hard to identify, in the literature there are many attempts to unravel those. For example, Aghion, Peter and Fabrice (2010) investigated the relation between economic growth and life expectancy and found the positive correlation between them. Barro and Sala-i Martin (2004) proved that higher level of life expectancy was acting as enhancer of economic growth. Many studies support these results (Bloom, Canning \& Sevilla, 2001; Sala-i Martin, Doppelhofer \& Miller, 2004). Some of them investigated the relationship between economic activities and the health expenditure convergence which presumably increase the longevity. Nixon (1999) proved the existence of the health expenditure-convergence among EU countries and the health expenditure of lagging countries converged to the mean of the health expenditures of EU countries. Kerem, Puss and Maldre (2008) found the convergence speed of health care expenditures of EU countries as 7\%.

Table 5. The life expectancy statistics (1980-2009)

\begin{tabular}{lcccc}
\hline & 1980 & 1990 & 2000 & 2009 \\
\hline Minimum & 68.808 & 69.273 & 70.365 & 71.821 \\
Maximum & 75.743 & 77.536 & 79.648 & 81.945 \\
Mean & 72.289 & 73.945 & 75.976 & 78.125 \\
\hline
\end{tabular}

Table 5 shows the life expectancy level among EU countries between 1980 and 2009. According to these statistics, the minimum level of the life expectancy, Latvia has 68 in 1980 and Lithuania has 71 in 2009 , increases in thirty years. Besides, the maximum level of the life expectancy increases from 75(Netherlands) to 81(Italy) and the average life expectancy increases from 72 to 78 in the last three decades.

Table 6. The logarithm of life expectancy statistics (1980-2009)

\begin{tabular}{lcccc}
\hline & 1980 & 1990 & 2000 & 2009 \\
\hline Minimum & 4.231 & 4.238 & 4.253 & 4.274 \\
Maximum & 4.327 & 4.350 & 4.377 & 4.406 \\
Mean & 4.280 & 4.302 & 4.329 & 4.357 \\
Standard Deviation & 0.030 & 0.037 & 0.040 & 0.041 \\
Coefficient of Variation & 0.007 & 0.008 & 0.009 & 0.009 \\
\hline
\end{tabular}

Table 6 represents the statistics of the logarithm of the life expectancy between 1980 and 2009. According to these results, the standard deviation and coefficient of variation of the logarithm of life expectancy increase continuously between 1980 and 2000, and they show a stable trend between 2000 and 2009. These results show that there is an increase of the life expectancy among EU members between 1980 and 2009, but there is no decrease in the distribution of the logarithm of life expectancy. This can be interpreted that the countries which 
have lower longevity have some troubles to catch up the life expectancy level of higher longevity countries in the Union. So the dispersion of the life expectancy stayed stable or increased between 1980 and 2009.

Crespo-Cuaresma et al. (2002)'s conditional convergence model is applied to test the existence of the conditional life expectancy convergence among EU countries with using the panel data regression. The variable explanations are given in the Table 3 and the model is

$$
\left[\ln \left(\mathrm{L}_{t, i}^{\prime}\right)-\ln \left(L_{t, i}\right)\right] / n_{t}=\alpha+\beta \cdot \ln \left(L_{t, i}\right)+\beta_{2} \cdot O P E N_{t, i}+\beta_{3} I N F_{t, i}+\beta_{4} I N V_{t, i}+\beta_{5} \cdot G O V E X P_{t, i}+\beta_{6} \cdot S C H_{t, i}+\beta_{7} \cdot N O Y_{t, i}+\beta_{8} \cdot D U M M Y_{t, i}+u_{t, i}(3)
$$

\subsubsection{Results}

Literature showed that there is a very strong positive relationship between per capita income and health expenditures. So through increasing income level we expect EU membership to increase expected lifetime. As mentioned before, the coefficients of openness, investment rate, EU membership, and length of EU membership increase the per capita income growth whereas inflation decreases it. The longevity of a society is related with income, technology and many other variables but the income level is extremely important for longevity. Rosen (1988) reported that individuals and/or societies can be willing to pay more to improve their longevity when their income increases. So, it is expected that these variables can affect the life expectancies of the countries indirectly. In addition, we used dummy variable for testing the effectiveness of EU in previous section and showed that the membership increased the economic growth by $1.6 \%$. In the same way, the life expectancy of EU countries can be increased because of positive effect of membership.

Table 7. Conditional $\beta$ life expectancy convergence in EU (1980 - 2009)

\begin{tabular}{lcc}
\hline Fixed Effect (within) regression & Coefficients & Standard Error \\
\hline Constant & $0.1930^{* * *}$ & $(0.5452)$ \\
Life Expectancy & $-0.0462^{* * *}$ & $(0.0127)$ \\
Openness & $0.00002^{* * *}$ & $(6.99 \mathrm{e}-06)$ \\
Inflation & $2.28 \mathrm{e}-06$ & $(4.97 \mathrm{e}-06)$ \\
Investment Rate & $0.00008^{* *}$ & $(0.00004)$ \\
Government Expenditure Rate & 0.00004 & $(0.00004)$ \\
School Attainment & 0.0001 & $(0.0002)$ \\
Number of Year & $0.00008^{* *}$ & $(0.00004)$ \\
Dummy & $0.0008^{* *}$ & $(0.0004)$ \\
Observations & 73 & \\
\hline & within & 0.6603 \\
$\mathrm{R}^{2}$ & between & 0.0335 \\
& overall & 0.1037 \\
\hline
\end{tabular}

Note: All EU countries with data ranging from 1980 to 2009, divided into three periods: 1980-1989, 1990-1999 and 2000-2009. Robust standard errors in parenthesis. $* * *(* *)[*]$ means $1 \%(5 \%)[10 \%]$ significant. According to the Hausman Test, fixed effect panel data regression is more appropriate than random effect regression. The results are obtained with using STATA 11.

The results of model (3) are shown in Table 7. The estimated coefficient of the logarithm of the initial life expectancy, $-0.0462(0.0127)$, means that a one standard deviation increase in the logarithm of the initial life expectancy $(0.04$ in 2000$)$ reduces the growth rate of longevity by 0.002 . That shows the existence of the convergence that the lower longevity countries' life expectancy levels grow faster than the higher ones.

The estimated openness coefficient, 0.00002 (6.99e-06), shows the positive relationship between openness and life expectancy growth rate. Also, the estimated investment coefficient, $0.00008(0.00004)$, shows that when investment rate increases, the longevity is affected positively. Both of these coefficients are highly significant, whereas the coefficients of the government expenditure, inflation, and school attainment are not statistically significant. The estimated NOY coefficient, 0.00008 (0.000 04), implies that the former members' longevity level take advantage of union membership more than the newly members. The estimated coefficient on EU 
membership dummy, $0.0008(0.0004)$, means that the membership raises the life expectancy growth at least by $0.08 \%$. These results are positive and significant at $5 \%$ confidence intervals.

The convergence speed is almost $6 \%$. The speed of life expectancy convergence is quite slow as compared with the speed of the economic convergence. The developed countries are generally institutionalized and institutionalization has a crucial impact on longevity and health status of countries (Baum et al., 2003). The institutionalization process and the influence of income increase on the health level of the individuals can take long time in the developing countries (Acemoglu \& Robinson, 2012). Thus developing countries have difficulties to catch up the developed countries in the short run.

The new members start to increase their per capita income and life expectancy with the benefits from the opportunities provided by EU. Although small in magnitude, EU is acting like a life expectancy enhancer. So, the EU membership has positive impact not only quality of life (consumption and income level) but also quantity (expected lifetime) of life in member countries.

\section{Welfare Convergence in $\mathbf{E U}$}

The full income is a combination of income per capita and expected lifetime and gives the monetary value to the increases in life expectancy in a period. Also, welfare function includes the income change and value of gaining life in a period, so increase in these variables will enhance the welfare of the society. In the previous sections, increases in income and expected lifetime are shown, so an increase in the welfare is expected with EU membership.

\subsection{Full Income}

The methodology of full income was coined by Usher (1973) and developed by Rosen (1988). After that, Becker et al. (2005) and Soares (2007) further developed and simplified this methodology. We will use their method to obtain the monetary value of lifetime. This methodology can be defined as follows. The indirect utility function $\mathrm{V}(\mathrm{Y}, \mathrm{S})$ where $\mathrm{Y}$ is the lifetime income and $\mathrm{S}$ is the survival function.

$$
V(Y, S)=\max \int_{0}^{\infty} \exp (-\rho t) \cdot S(t) \cdot u(c(t)) \cdot d t
$$

subject to

$$
Y=\int_{0}^{\infty} \exp (-r t) \cdot S(t) \cdot y(t) d t=\int_{0}^{\infty} \exp (-r t) \cdot S(t) \cdot c(t) d t
$$

Survival function shows the survival probability of an individual in a period. In this study, we will assume that each individual's lifetime is the average life expectancy of the country in a specific period, so if an individual is alive, survival function will be equal to 1 , inversely, if he is dead, it will be 0 . We can simplify this equation by this assumption.

$$
V(Y, L)=\max \int_{0}^{L} \exp (-\rho t) \cdot u(c(t)) d t
$$

subject to

$$
Y=\int_{0}^{L} \exp (-r t) \cdot y(t) d t=\int_{0}^{L} \exp (-r t) \cdot c(t) d t
$$

where $\mathrm{L}$ refers the lifetime, $\mathrm{y}(\mathrm{t})$ is the per capita income and $\mathrm{c}(\mathrm{t})$ is the consumption at age $\mathrm{t}, \mathrm{r}$ is interest rate and $\rho$ is subjective discount rate and $\mathrm{u}($.$) is the utility function.$

As mentioned by Rosen (1988), the value of lifetime can be measured with willingness to pay for increasing longevity. So we can define income equivalent compensation that an additional income which provides reaching to the next period's utility with initial life expectancy level. In other words, Y refers the initial level total lifetime income and $\mathrm{L}$ is the life expectancy at first period whereas $\mathrm{Y}^{\prime}$ implies the total income and $\mathrm{L}^{\prime}$ is the life 
expectancy in the second period. These periods are any two time of an individual's life. We can define the income equivalent compensation as follows;

$$
V\left(Y^{\prime}+F, L\right)=V\left(Y^{\prime}, L^{\prime}\right)
$$

In one sense, F shows the willingness of the individual for reaching to next period's level of life expectancy. So, $F$ can be defined as the total value of the gaining life expectancy $\left(\mathrm{L}^{\prime}-\mathrm{L}\right)$ in terms of income throughout the life of the individual. The methodology can be simplified with some assumptions as offered by Becker et al. (2005) and Soares (2007) such as, $\rho=\mathrm{r}$ and $\mathrm{c}(\mathrm{t})=\mathrm{c}=\mathrm{y}(\mathrm{t})=\mathrm{y}$. Consumption (c) and income (y) at age $\mathrm{t}$ are constants. Becker et al. (2005) and Soares (2007) defined the hypothetical life-cycle individual as a representative individual who is earning the average per capita income of the country and his total longevity is equal to the average level of the country's life expectancy. With the help of this definition, the indirect utility function can be defined in terms of yearly income.

$$
V(y, S)=u(y) \cdot \int_{0}^{\infty} \exp (-r t) \cdot S(t) d t=u(y) \cdot A(S)
$$

Becker et al. (2005) defined the equation of

$$
A(S)=\int_{0}^{\infty} \exp (-r t) \cdot S(t) d t \quad \text { as an annuity depended on the survival }
$$

function. According to our assumptions, the hypothetical individual lives as much as the average life expectancy of country in a specific period. The probability of this individual's living is $100 \%$ until the age of the average life expectancy of country. So, the survival function gives the value of 1 until the average level of life expectancy of the country, after that age it gives the value of 0 . Thus, the indirect utility function can be simplified,

$$
V(y, L)=u(y) \cdot \int_{0}^{L} \exp (-r t) d t=u(y) \cdot A(L)
$$

As defined by Soares (2007) the value of annuity can be written as,

$$
A(L)=\frac{1-\exp (-r L)}{r}
$$

Income equivalent compensation $\mathrm{F}$ shows the total value of gaining longevity in terms of per capita total lifetime income. Also, Becker et al. (2005) and Soares (2007) defined the yearly income equivalent compensation which is called full income and showed with " $\mathrm{f}$ " to measure the value of gaining life expectancy in terms of yearly per capita income. Full income can be represented as

$$
u\left(y^{\prime}+f\right) \cdot A(L)=u\left(y^{\prime}\right) \cdot A\left(L^{\prime}\right)
$$

So we degrade the income equivalent compensation into years and $y^{\prime}$ is the yearly per capita income in the last year whereas $y$ is the initial per capita income level of a period. Accordingly, the monetary value of the total gain in welfare of society, which can be defined with gaining per capita income and monetary value of lifetime in a period, can be written as

$$
\begin{aligned}
& f+\left(y^{\prime}-y\right) \\
& \frac{f}{f+\left(y^{\prime}-y\right)}
\end{aligned}
$$

shows the fraction of life expectancy in the welfare improvement and

$$
\frac{y^{\prime}-y}{f+\left(y^{\prime}-y\right)}
$$

implies the fraction of income in the welfare improvement. 
According to this methodology, welfare depends on income and longevity. So, an increase in these indicators will enhance the welfare. Rosen (1988) defined the utility function depended on income and intertemporal substitution.

$$
u(c)=\frac{c^{1-\frac{1}{\gamma}}}{1-\frac{1}{\gamma}}+\alpha
$$

As defined by Becker et al. (2005) and Soares (2007), $\alpha$ is the minimum consumption level of an individual and $\gamma$ is intertemporal elasticity of substitution. Also,

$$
\begin{gathered}
\varepsilon=\frac{u^{\prime}(c) \cdot c}{u(c)}=\frac{c^{1-\frac{1}{\gamma}}}{\frac{c^{1-\frac{1}{\gamma}}}{1-\frac{1}{\gamma}}+\alpha} \\
\alpha=c^{1-\frac{1}{\gamma}} \cdot\left(\frac{1}{\varepsilon}-\frac{1}{1-\frac{1}{\gamma}}\right)
\end{gathered}
$$

In this way, we adhere to values of $\varepsilon$ and $\gamma$ used by Becker et al. (2005). $\quad \varepsilon$ is equal to 0.346 and $\gamma=1.25$. We calculate $\alpha$ values with using these values and midyear real GDP per capita - midyear is 1995 for thirty year period - for each EU country.

We can obtain the equation of full income with inverting the equation (12) (Soares, 2007).

$$
f=u^{-1} \cdot\left[\frac{u\left(y^{\prime}\right) \cdot A\left(L^{\prime}\right)}{A(L)}\right]-y^{\prime}
$$

We obtain the extended equation of full income with inverting utility function (Becker et al., 2005);

$$
f=\left[y^{\prime\left(1-\frac{1}{\gamma}\right)} \cdot \frac{A\left(L^{\prime}\right)}{A(L)}+\alpha \cdot\left(1-\frac{1}{\gamma}\right) \cdot\left(\frac{A\left(L^{\prime}\right)-A(L)}{A(L)}\right)\right]^{\frac{\gamma}{\gamma-1}}-y^{\prime}
$$

This expression shows full income which is the monetary value of the gaining life expectancy in terms of per capita income. The growth rate of welfare will be calculated as

$$
g=\frac{y^{\prime}+f}{y}
$$

and the value of total lifetime - income equivalent compensation - can be explained by the following function (Becker et al., 2005);

$$
F=f \cdot \int_{0}^{L} \exp (-r t) d t=f \cdot A(L)
$$


Table 8. Welfare growth rate in EU (1980 - 2009)

\begin{tabular}{|c|c|c|c|}
\hline Member states of the EU & 1980-1989 & 1990-1999 & 2000-2009 \\
\hline Austria (1995) & 0.212 & 0.219 & 0.121 \\
\hline Belgium (1957) & 0.205 & 0.178 & 0.097 \\
\hline Bulgaria (2007) & 0.405 & -0.156 & 0.665 \\
\hline Cyprus (2004) & 0.567 & 0.229 & 0.197 \\
\hline Czech Republic (2004) & & 0.033 & 0.434 \\
\hline Denmark (1973) & 0.215 & 0.227 & 0.048 \\
\hline Estonia (2004) & 0.216 & 0.005 & 0.683 \\
\hline Finland (1995) & 0.315 & 0.147 & 0.304 \\
\hline France (1957) & 0.204 & 0.149 & 0.068 \\
\hline Germany (1957) & 0.220 & 0.183 & 0.142 \\
\hline Greece (1981) & 0.048 & 0.138 & 0.403 \\
\hline Hungary (2004) & 0.201 & 0.058 & 0.391 \\
\hline Ireland (1973) & 0.292 & 0.722 & 0.211 \\
\hline Italy (1957) & 0.274 & 0.149 & 0.026 \\
\hline Latvia (2004) & 0.358 & -0.209 & 0.823 \\
\hline Lithuania (2004) & & -0.279 & 0.919 \\
\hline Luxembourg (1957) & 0.521 & 0.372 & 0.190 \\
\hline Malta (2004) & 0.441 & 0.444 & 0.146 \\
\hline Netherlands (1957) & 0.163 & 0.255 & 0.176 \\
\hline Poland (2004) & & 0.407 & 0.499 \\
\hline Portugal (1986) & 0.344 & 0.275 & 0.066 \\
\hline Romania (2007) & 0.097 & -0.139 & 0.946 \\
\hline Slovak Republic (2004) & & 0.031 & 0.750 \\
\hline Slovenia (2004) & & 0.175 & 0.481 \\
\hline Spain (1986) & 0.259 & 0.242 & 0.150 \\
\hline Sweden (1995) & 0.227 & 0.148 & 0.173 \\
\hline United Kingdom (1973) & 0.305 & 0.224 & 0.180 \\
\hline
\end{tabular}

Table 8 represents the monetary value of overall gain in welfare's growth rate $(\mathrm{g})$ in ten year periods. As seen in table, the welfare growth of former members, which are generally higher per capita income and longevity, is decreasing broadly. Besides, the recent members tend to increase their welfare especially in the last decade and their welfare growth rate is much more than the former ones between 2000 and 2009 in general. This findings show that the last members show an amazing success to catch up the level of developed members and improve their welfare more than the developed ones.

Table 9. Statistics of full income (1980 - 2009)

\begin{tabular}{lccc}
\hline & $1980-1989$ & $1990-1999$ & $2000-2009$ \\
\hline Minimum & 11.228 & -3.789 & 60.473 \\
Maximum & 696.797 & 1130.645 & 1910.496 \\
Mean & 271.650 & 278.669 & 469.208 \\
Standard Deviation & 198.808 & 245.666 & 380.217 \\
Coefficient of Variation & 0.731 & 0.881 & 0.810 \\
\hline
\end{tabular}


Table 9 represents the summary statistic of full income between 1980 and 2009. The methodology of constructing the full income makes the change in the full income more meaningful than the level of full income. The value of minimum full income increases from 11.22 in 1980-1989 period to 60.4 in 2000-2009 period and maximum full income reaches to 1910.496 in the last decade. The average full income of 27 EU countries increases by $183 \%$ in last 3 decades and reaches to 469.2 . According to these statistics, the quality of living in EU decreases in 1990-1999 period mostly due to decreases in the income level in transition countries. Another point is the dispersion of full income; it increases in the thirty year our data covers. The inequality between EU countries goes up especially in 1990-1999 period. The standard deviation increases from 198 to 380 . Also, the coefficient of variation enhances to 0.88 in $1990-1999$ period, and then it decreases to 0.81 in 2000 s. So, the welfare inequality tends to decrease in the last decade.

Table 10. Gaining income, life expectancy and welfare (1980-2009)

\begin{tabular}{lccllllllll}
\hline & \multicolumn{3}{c}{ Per Capita Income } & \multicolumn{3}{c}{ Full Income } & \multicolumn{3}{c}{ Welfare } \\
\hline Members & $1980-9$ & $1990-9$ & $2000-9$ & $1980-9$ & $1990-9$ & $2000-9$ & $1980-9$ & $1990-9$ & $2000-9$ \\
\hline Austria & 2815 & 3728 & 2240 & 563 & 506 & 645 & 3379 & 4235 & 2886 \\
Belgium & 2673 & 3204 & 1510 & 516 & 303 & 637 & 3190 & 3507 & 2148 \\
Bulgaria & 511 & -183 & 941 & 12 & -3 & 60 & 524 & -187 & 1002 \\
Cyprus & 3558 & 2232 & 2085 & 183 & 217 & 190 & 3742 & 2449 & 2275 \\
Czech R. & & -14 & 1704 & & 192 & 206 & & 178 & 1911 \\
Denmark & 4061 & 4967 & 554 & 170 & 498 & 684 & 4232 & 5466 & 1239 \\
Estonia & 686 & -56 & 1968 & 53 & 52 & 348 & 740 & -3 & 2317 \\
Finland & 4539 & 2452 & 2981 & 291 & 570 & 765 & 4831 & 3022 & 3746 \\
France & 2752 & 2434 & 906 & 427 & 357 & 602 & 3180 & 2792 & 1508 \\
Germany & 2961 & 3001 & 1295 & 476 & 562 & 546 & 3437 & 3563 & 1841 \\
Greece & 225 & 1239 & 3343 & 233 & 111 & 384 & 458 & 1350 & 3727 \\
Hungary & 715 & 163 & 1143 & 22 & 75 & 248 & 737 & 238 & 1392 \\
Ireland & 2758 & 9620 & 3122 & 168 & 374 & 1044 & 2927 & 9995 & 4166 \\
Italy & 3114 & 2061 & -789 & 470 & 395 & 463 & 3584 & 2456 & -325 \\
Latvia & 1056 & -835 & 1670 & 76 & 18 & 236 & 1132 & -817 & 1907 \\
Lithuania & & -1154 & 1886 & & 14 & 61 & & -1139 & 1948 \\
Luxemburg & 10221 & 10943 & 5930 & 696 & 1130 & 1910 & 10917 & 12074 & 7840 \\
Malta & 1822 & 2795 & 649 & 154 & 156 & 136 & 1976 & 2951 & 786 \\
Netherland & 2241 & 4582 & 1914 & 175 & 216 & 661 & 2416 & 4799 & 2575 \\
Poland & & 1153 & 1876 & & 108 & 152 & & 1261 & 2028 \\
Portugal & 1963 & 2228 & 145 & 264 & 261 & 329 & 2228 & 2489 & 474 \\
Romania & 168 & -279 & 955 & 11 & 15 & 95 & 179 & -263 & 1050 \\
Slovak R. & 531 & 37 & 2715 & & 123 & 213 & & 160 & 2928 \\
Slovenia & & 1278 & 2577 & & 175 & 554 & & 1454 & 3132 \\
Spain & 2125 & 2498 & 1111 & 157 & 244 & 331 & 2282 & 2743 & 1443 \\
Sweden & 3999 & 3237 & 3020 & 454 & 470 & 520 & 4453 & 3707 & 3540 \\
UK & 4374 & 4136 & 2169 & 394 & 372 & 634 & 4769 & 4508 & 2804 \\
\hline & & & & & & & & & \\
\hline
\end{tabular}


Table 10 shows the gaining per capita income, the monetary value of life expectancy (full income) and the monetary value of gaining welfare which is the sum of gaining per capita income and life expectancy in terms of yearly income. According to table, the developed countries have higher income, full income and welfare, whereas newly members, which are in middle and east of Europe, have lower ones. As is seen easily, the period of 1990-1999 is problematic for these countries. In this period, the quality and quantity of life is decreasing, but they tend to recover their economic and socio-economic components in the beginning of $21^{\text {th }}$ century. Especially, the income, full income and the value of welfare of these countries are increasing in the last decade and especially welfare improvement is catching up the level of developed ones.

Table 11. Income and life expectancy fractions in welfare gain (1980-2009)

\begin{tabular}{|c|c|c|c|c|c|c|c|c|c|}
\hline & \multicolumn{3}{|c|}{ Welfare Gain } & \multicolumn{3}{|c|}{ Income Fraction } & \multicolumn{3}{|c|}{ Life Expectancy Fraction } \\
\hline Members & $1980-9$ & $1990-9$ & $2000-9$ & $1980-9$ & $1990-9$ & $2000-9$ & $1980-9$ & $1990-9$ & $2000-9$ \\
\hline Austria & 3379 & 4235 & 2886 & 0.83 & 0.88 & 0.78 & 0.17 & 0.12 & 0.22 \\
\hline Belgium & 3190 & 3507 & 2148 & 0.84 & 0.91 & 0.70 & 0.16 & 0.09 & 0.30 \\
\hline Bulgaria & 524 & -187 & 1002 & 0.98 & 0.98 & 0.94 & 0.02 & 0.02 & 0.06 \\
\hline Cyprus & 3742 & 2449 & 2275 & 0.95 & 0.91 & 0.92 & 0.05 & 0.09 & 0.08 \\
\hline Czech R. & & 178 & 1911 & & 0.92 & 0.89 & & 0.08 & 0.11 \\
\hline Denmark & 4232 & 5466 & 1239 & 0.96 & 0.91 & 0.45 & 0.04 & 0.09 & 0.55 \\
\hline Estonia & 740 & -3 & 2317 & 0.93 & 0.99 & 0.85 & 0.07 & 0.01 & 0.15 \\
\hline Finland & 4831 & 3022 & 3746 & 0.94 & 0.81 & 0.80 & 0.06 & 0.19 & 0.20 \\
\hline France & 3180 & 2792 & 1508 & 0.87 & 0.87 & 0.60 & 0.13 & 0.13 & 0.40 \\
\hline Germany & 3437 & 3563 & 1841 & 0.86 & 0.84 & 0.70 & 0.14 & 0.16 & 0.30 \\
\hline Greece & 458 & 1350 & 3727 & 0.49 & 0.92 & 0.90 & 0.51 & 0.08 & 0.10 \\
\hline Hungary & 737 & 238 & 1392 & 0.97 & 0.68 & 0.82 & 0.03 & 0.32 & 0.18 \\
\hline Ireland & 2927 & 9995 & 4166 & 0.94 & 0.96 & 0.75 & 0.06 & 0.04 & 0.25 \\
\hline Italy & 3584 & 2456 & -325 & 0.87 & 0.84 & 0.42 & 0.13 & 0.16 & 0.58 \\
\hline Latvia & 1132 & -817 & 1907 & 0.93 & 0.98 & 0.88 & 0.07 & 0.02 & 0.12 \\
\hline Lithuania & & -1139 & 1948 & & 0.97 & 0.97 & & 0.03 & 0.03 \\
\hline Luxemburg & 10917 & 12074 & 7840 & 0.94 & 0.91 & 0.76 & 0.06 & 0.09 & 0.24 \\
\hline Malta & 1976 & 2951 & 786 & 0.92 & 0.95 & 0.83 & 0.08 & 0.05 & 0.17 \\
\hline Netherland & 2416 & 4799 & 2575 & 0.93 & 0.95 & 0.74 & 0.07 & 0.05 & 0.26 \\
\hline Poland & & 1261 & 2028 & & 0.91 & 0.92 & & 0.09 & 0.08 \\
\hline Portugal & 2228 & 2489 & 474 & 0.88 & 0.90 & 0.31 & 0.12 & 0.10 & 0.69 \\
\hline Romania & 179 & -263 & 1050 & 0.94 & 0.94 & 0.91 & 0.06 & 0.06 & 0.09 \\
\hline Slovak R. & & 160 & 2928 & & 0.23 & 0.93 & & 0.77 & 0.07 \\
\hline Slovenia & & 1454 & 3132 & & 0.88 & 0.82 & & 0.12 & 0.18 \\
\hline Spain & 2282 & 2743 & 1443 & 0.93 & 0.91 & 0.77 & 0.07 & 0.09 & 0.23 \\
\hline Sweden & 4453 & 3707 & 3540 & 0.90 & 0.87 & 0.85 & 0.10 & 0.13 & 0.15 \\
\hline UK & 4769 & 4508 & 2804 & 0.92 & 0.92 & 0.77 & 0.08 & 0.08 & 0.23 \\
\hline
\end{tabular}

Table 11 shows the fractions of life expectancy and income in welfare improvement. The majority of welfare improvement is created by the increases in per capita income, especially in the new members. This is expected, because the membership initially influences the members economically. The social effects can be slower than the economic effects in Union. However, the life expectancy fraction in welfare tends to increase and it causes to increase in welfare.

\subsection{The Conditional $\beta$ Welfare Convergence}

Rosen (1988) pointed out that consumption elasticity is the main determinant of value of expected lifetime increases, because if an individual is rich, he can and willing to give up more money for life extensions. The income level affects the willingness of paying for increase in longevity. Becker et al. (2005) investigated 49 countries between 1965 and 1995 and proved that although there was not income convergence, the full income convergence existed among these countries. Besides, they tried to explain the reduction of mortality with 13 different illness groups and compared the developing and the developed countries in terms of the effects of these 
diseases. According to their results, the developed countries are affected from the illnesses more than the developing countries. The most interesting points proved in this study are the high income countries' welfare growth is lower than the developing countries and the positive effect of increase in longevity on welfare in the developing countries is more than in the developed countries. Soares (2007) investigated the Brazilian municipalities between 1970 and 2000 and proved the increase in longevity at least 5 years and longevity convergence among municipalities. Murphy and Topel (2003) proved that the higher level income can increase the longevity and willingness to pay for increase in longevity, whereas reduce the mortality rate.

We defined the welfare as monetary value of increase in longevity and income as equation (13) in a period. The value of welfare improvement will be zero in the beginning, because there is no increase income or life expectancy initially and the initial level welfare will be equal to income level. We will use Crespo-Cuaresma et al. (2002)'s model which was used for analyzing the conditional convergence among EU economies. This model testing conditional convergence of income and life expectancy in previous sections will be modified for monetary value of welfare as follows;

$$
g=\alpha+\beta \cdot y_{t, i}+\beta_{2} \cdot \text { OPEN }_{t, i}+\beta_{3} \cdot I_{N F_{t, i}}+\beta_{4} \cdot I N V_{t, i}+\beta_{5} \cdot G O V E X P_{t, i}+\beta_{6} \cdot S C H_{t, i}+\beta_{7} \cdot N O Y_{t, i}+\beta_{8} \cdot D U M M Y_{t, i}+u_{t, i}
$$

$\mathrm{g}$ is the welfare growth rate calculating with the equation (21). The detailed information about the control variables is mentioned in Table 3.

\subsubsection{Results}

The regression results of model (23) are shown in Table 12. The estimated coefficient of initial welfare level, $-0.0004(0.0001)$, is negative and highly significant. It is significant at $1 \%$ confidence intervals. The negative sign implies the existence of the conditional $\beta$ welfare convergence that the developing countries' growth rate of the welfare improvement is faster than the developed countries. A one standard deviation decrease in the initial welfare, which is the initial per capita income level (11 159 in 2000) raises the welfare growth rate on impact by 4.46. However, the speed of the convergence is not very high $(0.4 \%)$.

Table 12. Conditional $\beta$ welfare convergence in EU (1980 - 2009)

\begin{tabular}{llc}
\hline Fixed Effect (within) regression & Coefficients & Standard Error \\
\hline Constant & 0.0731 & $(0.4974)$ \\
Initial Welfare Level & $-0.0004^{* * *}$ & $(0.0001)$ \\
Openness & $0.0043^{* *}$ & $(0.0019)$ \\
Inflation & -0.0029 & $(0.0018)$ \\
Investment Rate & 0.0086 & $(0.0085)$ \\
Government Expenditure Rate & -0.0073 & $(0.0112)$ \\
School Attainment & -0.0629 & $(0.0424)$ \\
Number of Year & 0.0065 & $(0.0101)$ \\
Dummy & $0.1623^{* *}$ & $(0.0741)$ \\
Observations & 72 & \\
\hline & within & 0.7373 \\
$\mathrm{R}^{2}$ & between & 0.2003 \\
& overall & 0.3551 \\
\hline
\end{tabular}

Note: All EU countries with data ranging from 1980 to 2009, divided into three periods: 1980-1989, 1990-1999 and 2000-2009. Robust standard errors in parenthesis. $* * *(* *)[*]$ means $1 \%(5 \%)[10 \%]$ significant. According to the Hausman Test, fixed effect panel data regression is more appropriate than random effect regression. The results are obtained with using STATA 11.

The openness, $0.0043(0.0019)$, is positive and significant at $5 \%$ confidence intervals. A one standard deviation increase in the openness rate $(0.48$ in 2000$)$ raises the welfare growth rate by 0.002 . The positive sign of the estimated coefficient of openness is expected because of the positive effects on per capita income and life expectancy. As shown in previous sections, though the estimated coefficient of inflation is insignificant in conditional life expectancy convergence, the income is affected negatively and significantly from the inflation rate. There is positive relationship between investment rate and welfare. The estimated coefficient is positive but insignificant. The investment can be increasing in developing countries due to the potential contributions from common market. So, this can affect the economic activities positively. Many studies touched on that the 
investment rate influence the GDP growth positively (Barro \& Sala-i Martin, 2004; Crespo-Cuaresma et al., 2002). According to our results, the investment rate affects GDP per capita and longevity positively. So, it is expected that the sign of the estimated coefficient of investment rate is positive. Dummy variable measures the effect of the EU membership on welfare. The estimated coefficient, 0.1623 (0.0741), means that union accession influences the welfare of members positively and it enhances the welfare growth rate about $16 \%$. Also, the coefficient is significant at $5 \%$ confidence intervals.

As a result, there is conditional $\beta$ welfare convergence among EU countries. The EU countries having lower initial welfare level grow faster than the EU countries with higher initial welfare levels. Besides, the high welfare growth rate can be obtained with Union membership.

\section{Conclusion}

Becker et al. (2005) states that, the quality of life (which depends on the consumption and the income level) is as important as the quantity of life, so both of these indicators affect the welfare. To analyze the welfare, we need a measurement which combines these different aspects of the welfare into single one. The method of full income is used to put a monetary value of improvements in life expectancy. The main goal of this paper is estimate the impact of EU membership on members' welfare which is defined as increasing living standards and life expectancy with using convergence methods. According to our results, EU membership influences the members' per capita income, longevity and welfare positively and developing countries tend to converge to the developed countries in EU.

The positive effect on economic growth can be realized with the economic opportunities provided by the union. The estimated $\beta$ coefficients, which are negative and highly significant, indicate the existence of conditional convergence among 27 member countries and the convergence speed is $17 \%$. Besides, we used the dummy variable to estimate the impact of EU membership. According to the results, the membership enhances the economic growth at least by $1.6 \%$. Although the income dispersion between EU countries reaches to top level in the end of 1990s and it starts to decrease in the beginning of 2000s and reaches to minimum level in 2009.

Another point which enhances the welfare is the life expectancy. In addition to former studies which proved the health expenditures convergence among members, the existence of life expectancy convergence in the union is shown. According to our findings, the conditional $\beta$ convergence is presented among members. The EU countries which have lower life expectancy level grow faster than the countries having higher life expectancy level. However, the life expectancy convergence rate is not as high as economic convergence rate, it is $6 \%$.

The full income methodology is used to describe the welfare which is a combination of per capita income and longevity. Full income can be defined as the monetary value of lifetime in terms of income and the willingness of paying for increase in longevity in a period. The monetary value of welfare is obtained by this concept. It is proved that the welfare of members which have higher initial income per capita and life expectancy level grow slower than the countries which have lower initial income and life expectancy in the union. This means that despite the slower convergence speed, there is welfare convergence among EU countries. The income, life expectancy and welfare of developing countries which are generally new member countries tend to reach the level of developed countries in EU. Besides, the membership affects the welfare of the members positively and the membership enhances the welfare growth by $16 \%$.

Consequently, the EU members have economic opportunities initially and they tend to achieve the goal of reaching the level of high income countries. In addition to increasing income level, the abolition of borders, transferring of technology, capital, investments and many other variables help to increase the life expectancy. Finally, the welfare of union increases as a result of increasing quality and quantity of life.

\section{References}

Acemoglu, D., \& Robinson, J. (2012). Why Nations Fail: The Origins of Power, Prosperity, and Poverty ( $1^{\text {st }}$ ed.). Crown Business, New York, USA.

Aghion, P., Peter, H., \& Fabrice, M. (2010). The relationship between health and growth: when Lucas meets Nelson-Phelps. NBER Working Paper no. 15813.

Barro, R., \& Sala-i Martin, H. (1992). Convergence. Journal of Political Economy, 100, 223-251. http://dx.doi.org/10.1086/261816

Barro, R., \& Sala-i Martin, H. (2004). Economic Growth (2nd ed.). MIT Press.

Barro, R., \& Lee, J. W. (2010). A New Data Set of Educational Attainment in the World, 1950-2010. NBER Working Paper no. 15902. 
Baum, J. K., Myers, R. A., Kehler, D. G., Worm, B., Harley, S. J., \& Doherty, P. A. (2003). Collapse and conservation of shark populations in the Northwest Atlantic. Science, 299, $389-392$. http://dx.doi.org/10.1126/science.1079777

Becker, G. S., Philipson, T. J., \& Soares, R. R. (2005). The quantity and quality of life and the evolution of world inequality. American Economic Review, 95(1), $277-291$. http://dx.doi.org/10.1257/0002828053828563

Beugelsdijk, M., \& Sylvester, C. W. (2005). The effectiveness of structural policy in the European Union: An empirical analysis for the EU-15 in 1995-2001. Journal of Common Market Studies, 43, 37-51. http://dx.doi.org/10.1111/j.0021-9886.2005.00545.x

Bloom, D., Canning, D., \& Sevilla, J. (2001). The effect of health on economic growth: Theory and evidence. NBER Working Paper no. 8587.

Caves, R. E., \& Barton, D. R. (1990). Efficiency in US manufacturing industries. MIT Press Cambridge, Mass.

Crespo-Cuaresma, J., Dimitz, M. A., \& Ritzberger-Grünwald, D. (2002). Growth effects of European integration: Implications for EU enlargement. Austrian National Bank, Focus on Transition, 1, 87-100.

Falk, M., \& Sinabell, F. (2008). The effectiveness of objective 1 structural funds in the EU 15: New empirical evidence from NUTS 3 regions. Working Paper no.310, WIFO.

Harrison, A. (1996). Openness and growth: A time-series, cross-country analysis for developing countries. Journal of Development Economics, 48(2), 419-447. http://dx.doi.org/10.1016/0304-3878(95)00042-9

Kar, M., \& Arıkan, H. (Eds.). (2003). Avrupa Birliği ortak politikalar ve Türkiye. İstanbul Beta Press.

Kerem, K., Puss, T., \& Maldre, R. (2008). Health and convergence of health care Expenditure in EU. International Business and Economics Research Journal, 2, 29-43.

Kutan, A. M., \& Yigit, T. M. (2007). European integration, productivity growth and real convergence. European Economic Review, 51, 1370-1395. http://dx.doi.org/10.1016/j.euroecorev.2006.11.001

Lee, J. W. (1992). International trade, distortions and long-run economic growth. International Monetary Fund, Research Department.

Lopez-Rodriguez, J. (2008). Regional Convergence in the European Union: Results from a Panel Data Model. Economics Bulletin, 18(2), 1-7.

Macdonald, J. M. (1994). Does import competition force efficient production? Review of Economics and Statistics, 76(4), 721-727. http://dx.doi.org/10.2307/2109773

Murphy, K., \& Topel, R. (2003). The economic value of medical research. In K. Murphy, \& R. Topel (Eds.), Measuring the Gains from Medical Research: An Economic Approach. The University of Chicago Press.

Nixon, J. (1999). Convergence analysis of health care expenditure using two approaches. Discussion Papers in Economics, 99(3). University of York.

Nordaus, W. (2002). The health of nations: the contribution of improved health to living standards. In K. Murphy, \& R. Topel (Eds.), The Economic Value of Medical Research. Chicago: University of Chicago Press.

Penn World Table 6.3, Retrieved February 2011, from http://pwt.econ.upenn.edu/

Philipson, T., \& Soares, R. (2001). Human capital, longevity and economic growth: a quantitative assessment of full income measures.

Reza, R., \& Zahra, K. T. (2008). Evaluation of the income convergence hypothesis in ten new members of the European Union. A panel unit root approach. Panoeconomicus, 2, 157-166.

Rosen, S. (1988). The value of changes in life expectancy. Journal of Risk and Uncertainty, 1, $285-304$. http://dx.doi.org/10.1007/BF00056139

Sachs, J., \& Warner, A. (1995). Economic reform and the process of global integration (with discussion). Brookings Papers on Economic Activity, 1, 1-118. http://dx.doi.org/10.2307/2534573

Sala-i Martin, X., Doppelhofer, G., \& Miller, R. (2004). Determinants of long- term growth: a Bayesian averaging of classical estimates (BACE) approach. American Economic Review, 94(4), 813-836. http://dx.doi.org/10.1257/0002828042002570 
Soares, R. R. (2007). Health and the evolution of welfare across Brazilian municipalities. Journal of Development Economics, 84(2), 590-608. http://dx.doi.org/10.1016/j.jdeveco.2007.02.002

Usher, D. (1973). An imputation of the measure of economic growth for changes in life expectancy. In M. Moss (Eds.), The Measurement of Economic and Social Performance, 38, 193-225. New York, National Bureau of Economic Research and Columbia University Press.

Vanhoudt, P. (1999). Did the European unification induce economic growth? In search of scale effects and persistent changes. Review of World Economics, 135(2), 193-220.

World Databank- World Development Indicators \& Global Development Finance. Retrieved February 2011 from http://data.worldbank.org/

\section{Notes}

Note 1. See Acemoglu and Robinson (2012) for an extensive discussion about historical examples of that.

Note 2. This model was used by Crespo-Cuaresma et al. (2002) for analyzing the conditional convergence among 15 EU countries between 1960 and 1998. 